\title{
Impact Assessment of Changing Fuel on Water Consumption in Kuwait's Power Station
}

\author{
Fahad Alhajri * , Danah E. Mesoudah ${ }^{* *}$ and Nour Y. Alhashlamoun ** \\ *( The Public Authority for Applied Education and Training ,Kuwait, Email: fahadahhajri73@gmail.com ) \\ **( College of Graduate Studies, Kuwait University, Kuwait) \\ ***( College of Graduate Studies, Kuwait University, Kuwait)
}

\begin{abstract}
Demands on electricity are in continuous increase and as a result an increase on water consumption and withdrawal. A huge expansion is done by Kuwait seven stations to meet the need of water and electricity using different combinations of four types of fuel (natural gas, gas oil, heavy fuel oil and crude oil). This study aims to determine the optimum fuel for reducing water consumption and cost without changing the capacity of electricity production in Kuwait. To attain that water consumption and/or withdrawal factor had been calculated for each fuel in each station depending on electricity and water consumption and production values, then cost of each mega watt produced had been determined using calculated cost of each fuel. It is concluded that natural gas is the least consuming water and least productivity for electricity where heavy fuel oil is the cheapest one and gas oil is the most expensive and most consuming water. However more time and detailed analysis are needed to determine the optimum fuel. Three scenarios had been assumed on different stations, best one was in Az-zour station when we decreased natural gas percentage and it was compensated by crude oil with keeping gas oil as it was. Consequently, it was noticed there was increase in water consumption and decrease in the cost: about 2 million Kuwait dinars. .
\end{abstract}

\section{INTRODUCTION}

Electricity is a primary part of human's daily life. Of course, there is a direct relation between population growth and demand on energy. Availability of energy resources plays vital role in meeting the increase in demand due to population growth. As a result, exploiting these resources is a must. We should get energy at a lower cost and lower water consumption. One term that is used to express the environment's ability to support a given population is called the Carrying Capacity. This is a global measurement; it may be determined by energy resources availability in a specific area and the consumption rate. It is a measure of sustainability within changing conditions (Zabel 2009). Kuwait has the world's fifth largest oil reserves and petroleum products now account for nearly $95 \%$ of export revenues and $80 \%$ of government income. It has proven that crude oil reserves of 104 billion barrels $\left(15 \mathrm{~km}^{3}\right)$, estimated to be $10 \%$ of the world's reserves. Currently, Kuwait pumps 2.9 million bpd and its full production capacity is a little over 3 million bpd, including oil production in the neutral region that it shares with Saudi Arabia, Kuwait oil production is expected to increase to 4 million bpd by 2020 (Kuwait.Fuel-Logistics.Capacity.Assessment).

Production is achieved by the following chief oil Kuwait companies:

- Kuwait Petroleum Corporation

- Kuwait Oil Company

- Kuwait National Petroleum Company

- Kuwait Foreign Petroleum Exploration Company

- Kuwait Oil Tanker Company

- Kuwait Aviation Fueling company

- Kuwait Gulf Oil Company

The following Table shows Energy in Kuwait through years, as it will be seen, production increased 15\% from 2004 to 2008 (Kuwait.FuelLogistics.Capacity.Assessment): 
Table 1: Energy in Kuwait (2004 - 2013)

\begin{tabular}{|c|c|c|c|c|c|c|}
\hline Year & $\begin{array}{c}\text { Capita } \\
\text { Million }\end{array}$ & $\begin{array}{c}\text { Prim. Energy } \\
\text { TWh }\end{array}$ & $\begin{array}{c}\text { Production } \\
\text { TWh }\end{array}$ & $\begin{array}{c}\text { Export } \\
\text { TWh }\end{array}$ & $\begin{array}{c}\text { Electricity } \\
\text { TWh }\end{array}$ & $\begin{array}{c}\mathbf{C O}_{2} \text {-emission } \\
\text { Mt }\end{array}$ \\
\hline $\mathbf{2 0 0 4}$ & 2.46 & 292 & 1,544 & 1,246 & 36.8 & 64.9 \\
\hline $\mathbf{2 0 0 7}$ & 2.66 & 293 & 1,705 & 1,398 & 43.1 & 66.8 \\
\hline $\mathbf{2 0 0 8}$ & 2.73 & 306 & 1,777 & 1,452 & 45.7 & 69.5 \\
\hline $\mathbf{2 0 0 9}$ & 2.80 & 351 & 1,515 & 1,146 & 46.6 & 80.7 \\
\hline $\mathbf{2 0 1 0}$ & 2.74 & 388 & 1,558 & 1,159 & 50.1 & 87.4 \\
\hline $\mathbf{2 0 1 2}$ & 2.82 & 378 & 1,795 & 1,401 & 50.38 & 84.74 \\
\hline $\mathbf{2 0 1 2 R}$ & 3.25 & 403 & 2,015 & 1,591 & 53.8 & 91.3 \\
\hline $\mathbf{2 0 1 3}$ & 3.37 & 408 & 1,983 & 1,559 & 53.6 & 84.1 \\
\hline Change 2004-10 & $11.4 \%$ & $33.0 \%$ & $0.9 \%$ & $-6.9 \%$ & $36.3 \%$ & $34.8 \%$ \\
\hline
\end{tabular}

Kuwait Power generating plants use different types of fossil fuels available such as natural gas, heavy fuel oil, crude oil and gas oil, depending on boiler design, such as that priority is given to natural gas within the limits of the available quantities. The older plants can burn natural gas and gas oil in case of emergency while the newer ones are able to burn the four types of fuel (Kuwait.Year.Book 2010).

\section{Electricity and Water Consumption and/or Withdrawal}

Water and energy are closely linked. Electricity generation units (EGUs) have a significant impact on water resources, since power plants withdraw and use much water. In EGUs water is used for two purposes, one is to be converted into steam which turns a turbine. The turbine turns a generator. The other purpose is for cooling and condensing the steam back to water. Several programs are developed to reduce the amount of freshwater withdrawal and consumption for existing and future power generation units (Feeley et al. 2007) There is a difference between water consumption and water withdrawal. Water consumption is defined as the amount of water that is evaporated or permanently removed from the immediate water environment, while water withdrawal refers to the amount of water removed from the surface water or groundwater source for use. Thus, water consumption is the total amount of withdrawal minus returned amount of water (AlHajeri et al. 2011). Water consumption is calculated in terms of the amount of water consumed to produce electricity - megawatt-hour (MWh). Each technology consumes a different amount of water as will be seen in the coming sections.

\section{Water Consumption and/or Withdrawal for Different Technologies in EGUs}

Depending on the configuration of the energy technology used, Electricity Generation Units (EGUs) use water for different processes. For example, for crude oil, water is used for enhanced oil extraction, processing and cooling. For natural gas, water is used in the drilling phase of natural gas wells as part of the drilling mud and for lubrication and cooling purposes. For coal systems, water is required during coal mining and cooling. Wind systems use very little water for cleaning, if any. For geothermal technologies, differences in reinjection techniques as well as vapor temperature and mass cause a difference in their use of water. Photovoltaic systems occasionally require panel washing and thus, water use. Practices indicate that most PV system operators do not wash panels (Macknick et al. 2012). For concentrated solar power facilities, water is used for cleaning mirrors, steam cycle processes, if cooling tower is used (Clark et al. 2011). The location of the plant and its corresponding climatic conditions, affect its overall efficiency and as a result, its water use rate (Giusti et al. , Miller et al. 1992, Dziegielewski et al. 2006, Yang et al. 2007). Consumption and withdrawal factors of water vary across and within fuel technologies, it was shown by Macknick and his partners that depending on the technology and cooling system employed, using less-carbon intensive electricity sector could results in an increase or decrease in water use (Macknick et al. 2012).

Types of Cooling Water in Thermal Power Plant Water is used for cooling either by oncethrough method or wet re-circulating (closed-loop) method, the later has much lower water withdrawals but higher water consumption and it's the most widely used method, whereas, very little plants use dry cooling method (which depends on cold air), because of its drawbacks in decreasing the efficiency and increasing the operating cost of power plants (Mielke et al. 2010). New steam turbines and combined-cycle turbine in recent power plants use closed-loop cooling while old plants use once-through cooling that are being replaced with closed-loop cooling systems. Water demand for the once-through system is 30 to 50 times that of a closed cycle system (Kumar et al. 2013). 
Most of water consumption in power generation units is due to cooling. Water withdrawal and consumption factors vary greatly across and within fuel technologies. For crude oil, water consumption depends on the type of generator used whether it's steam turbine, gas turbine or combined-cycle turbine. For natural gas, it occurs in small quantities and the net water-intensity is close to zero (Wu et al. 2009, Mielke et al. 2010).

\section{Electricity and Water in Kuwait}

Electricity has played a basic role for satisfying the different needs of Kuwait where essential goods and services production have been significantly developed in line with production development of electricity power in Kuwait. Electricity has entered Kuwait in 1913, production began with two generators, 30 kilowatts capacity of each where today, Kuwait is covered by wide electrical networks, some of which are air lines and others buried cables underground in addition to main and secondary switch plants and secondary distribution centers to secure conducting the electrical current for each consumer. Demands on electricity is in continuous increase and as a result an increase on water consumption and withdrawal. A huge progress by Kuwait in providing water for satisfying this increase in demand of electricity was achieved by water plants (Ministry.of.Water).

1- Al-Shuweikh Power Plant: this plant had been established in 1952, near the coast to get benefit of seawater in cooling process. The first plant was provided with steam for distilling seawater, its production has reached $33 \mathrm{MMkW} / \mathrm{hr}$, but now it's out of actual service due to less efficiency or lack of economic feasibility for repairing and rerunning.

2- Shuaiba North Plant: this was established by commencing operating of steam turbine in 1965 and now, the same happened with AlShuweikh plant, it's out of actual service.

3- Shuaiba South Plant: this began working in 1970, its electrical production has reached
$3032 \mathrm{MMkW} / \mathrm{hr}$ in 1998 and the compound capacity is 30 million emperor gallons on a daily basis.

4- Al-Doha East Plant: was operated in 1978 with three distillation units and now there're seven with a capacity of 42 million emperor gallons on a daily basis and by the end of 1984 it started electricity generation and production which has reached 11,010 MMkW/hr in 1998.

5- Al-Doha West Plant: it was operated in 1983 with three distillation units and now there're sixteen with capacity of 6 million emperor gallons on a daily basis and the total compound capacity of 1,104 million emperor gallons on a daily basis.

6- Al-Zour South Plant: was established in 1988 with five distillation units, three units were added in 1989, capacity of each is 6 million emperor gallons on a daily basis where its electrical production reached 101,212 MMkW in 1998.

The government efforts are clear in using most recent technologies the lead to reduce operation and maintenance costs and give higher production efficiency having a positive impact on production cost. Daily water demands for local and industry use exceeds the maximum capacity of all water plants, therefore, lower water consumption methods are necessary in all sectors.

\section{Kuwait Power Plants \& Data}

\section{METHODOLOGY}

Kuwait's electricity and water are produced from seven different stations, Shuwaikh, Shuaiba South and North, Doha East and West, Az-Zour South and Sabiya. Number of generation units ranges between $8-10$ generating units with diverse fuel types, including Natural Gas, Gas Oil, Crude Oil and Heavy Fuel Oil.

The following Table shows which fuel each station in Kuwait is currently using.

Table 2: Kuwait's Electricity and Water Production Stations and Fuels

\begin{tabular}{|c|c|c|c|c|c|c|}
\hline Shuwaikh & $\begin{array}{c}\text { Shuaiba } \\
\text { South }\end{array}$ & $\begin{array}{c}\text { Shuaiba } \\
\text { North }\end{array}$ & Doha East & Doha West & $\begin{array}{c}\text { Az-Zour } \\
\text { South }\end{array}$ & Sabiya \\
\hline NG & NG & NG & NG & NG & NG & NG \\
\hline- & - & GO & CO & HFO & GO & GO \\
\hline- & - & - & - & - & CO & HFO \\
\hline
\end{tabular}

Detailed engineering studies and more assessments of water use for each electricity generating station are uneven in their treatment of fuel gas and cooling technology used. Water consumption and/or withdrawal were considered for the operation of producing water since water is not consumed and/or withdrawn during cooling in Kuwait stations. Stations may utilize fresh or saline water resources during the process. Of course, different technologies use different amounts of 
water. Data under study had been collected from the Ministry of Water and Electricity of Kuwait for June, July and August 2014. Since July's data (mid-summer) showed the maximum water and electricity demand, For this study fuel consumption had been obtained by calculating heat content of fuel within each station, then both electricity as well as water consumption of each station had been calculated through percentage of each fuel consumed in each station and then, water production had been calculated. Estimation of water consumption and/or withdrawal are usually displayed irrespective of geographic location; many published data do not specify the location and climatic conditions of the plant although the overall efficiency of the plant can be affected by the location and the climatic conditions and thus affects its water use.

\section{Data Availability and Limitations}

Data provided for water consumption and/or withdrawal within the station was only to produce water in it, thus, eliminating direct consumption of water through cooling technologies (once-through cooling in Kuwait) during electricity production. The present work has yielded preliminary findings according to the available data and time but there is much remains to be done. An important limitation is that, the availability of data was not in a manner that helps to conduct a comparison between stations in sufficient way. A second limitation is the time limit; six weeks are not enough for a researcher to analyze all required data, since collection of data, checking as to accuracy, analysis and presentation often involve considerable time. Some justifications and assumptions had been considered and will be discussed in details in the coming sections for ease of optimization and calculations.

\section{Water Consumption Optimization}

Optimization is concerned with algorithmic aspects of maximizing or minimizing a specific objective function that is subject to constraints. For this study, maximum electricity production with minimum water consumed is desired.

Before calculating any value, heat content for all types of fuel had been calculated in BTU using conversion factors as it can be seen in the following table:

Table 3: Average Calorific values

\begin{tabular}{|ccc|}
\hline Fuel & C.V. & Unit \\
\hline HP Gas & $\mathbf{9 8 6}$ & BTU/SCF \\
\hline LP Gas & $\mathbf{1 1 1 8}$ & BTU/SCF \\
\hline Crude Oil & $\mathbf{5 . 4 8 0 E + 0 6}$ & BTU/bbl \\
\hline H.F.O. & $\mathbf{5 . 6 0 7 E + 0 6}$ & BTU/bbl \\
\hline LNG & $\mathbf{1 1 0 7 . 1}$ & BTU/SCF \\
\hline
\end{tabular}

An important factor had been calculated for each fuel in each station; that is consumption and withdrawal factor. It had been obtained by multiplying the total water consumed for electricity generation per electricity produced by the percentage of the fuel used in the station as shown in the following equation:

Water consumption and withdrawal factor $(\mathrm{MIG} / \mathrm{MW} \cdot \mathrm{h})=$

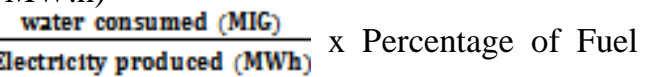

in each Station Equation 1
Unit of this factor is MIG/MW.h which describes the amount of water that is consumed to produce one Mega Watt of electricity in one hour by burning a specific percentage of fuel in that specific station. The cost of each fuel had been calculated through the following table, where it shows the cost of each fuel that is required for each Barrel or MSCF (for the case of Natural Gas):

Table 4: Cost of fossil fuel in KD

\begin{tabular}{|lcc|}
\hline Fuel & Price & Unit \\
\hline NG & 6.257 & KD/MSCF \\
\hline CO & 29.743 & $\mathrm{KD} / \mathrm{bbl}$ \\
\hline GO & 33.752 & $\mathrm{KD} / \mathrm{bbl}$ \\
\hline HFO & 25.769 & $\mathrm{KD} / \mathrm{bbl}$ \\
\hline
\end{tabular}


Gross price and cost of electricity produced by each fuel in the station had been calculated through the following fuel equations:

Gross Fuel Price $(\mathrm{KD})=$

Consumption of fuel (bbl) $x$ Cost of that fuel $\left(\frac{\mathrm{KD}}{\mathrm{bb}}\right) \ldots \ldots \ldots \ldots \ldots .$. Equation 2

Cost of electricity produced by each fuel $\left(\frac{\mathrm{KD}}{\mathrm{MWh}}\right)=$

Gross Fuel Price (KD)

Electricity produced by each fuel (MWh)

Equation 3

Cost of electricity produced by each fuel describes the cost of fuel burned to produce one Mega Watt of electricity in an hour.

Three different scenarios had been assumed in this study and then compared with the base case to examine the effect of fuel type percentage on water consumption and gross fuel price without changing the capacity of the station. The following table summarizes scenarios compared to the base case:

Table 5: Scenarios

\begin{tabular}{|cc|}
\hline Base Case & Scenario \\
\hline Doha East: (30\% NG, 70\% CO) & Doha East: (50\% CO, 50\% NG) \\
\hline Doha West: (30\% NG, 70\% HFO) & Doha West: (40\% HFO, 60\% NG) \\
\hline Az-Zour: (37.2\% CO, 1.6\% GO, 61.2\% NG) & Az-Zour: (68.4\% CO, $1.6 \%$ GO, 30\% NG) \\
\hline
\end{tabular}

Before considering any changes the capacity of each station should be considered and it is shown in the following Table:

Table 6: Kuwait Stations' Capacity

\begin{tabular}{|c|cc|}
\hline Station & $\begin{array}{c}\text { Steam Turbine } \\
\text { MW }\end{array}$ & $\begin{array}{c}\text { Gas Turbine } \\
\text { MW }\end{array}$ \\
\hline Shuwaikh & - & 252 \\
\hline Shuaiba & 720 & 660 \\
\hline Doha East & 1050 & 108 \\
\hline Doha West & 2400 & 112.8 \\
\hline AZ-Zour South & 2400 & 1976 \\
\hline Sabiya & 2400 & 500.2 \\
\hline
\end{tabular}

\section{RESULTS AND DISCUSSIONS}

Water Consumption and Withdrawal Factor

Electricity consumption, water consumption and water production in each station for each fuel had been calculated. Tables $7-9$ give brief summery for each fuel in each station. Table 13, demonstrates water consumed and electricity produced in each station.

Table 7: Electricity Consumption within Station for each fuel (MW.h/MBTU) $\times 10^{-2}$

\begin{tabular}{|cccccccc|}
\hline Fuel & Shuwaikh & $\begin{array}{c}\text { Shuaiba } \\
\text { South }\end{array}$ & $\begin{array}{c}\text { Shuaiba } \\
\text { North }\end{array}$ & Doha East & Doha West & $\begin{array}{c}\text { Az-Zour } \\
\text { South }\end{array}$ & Sabiya \\
\hline NG & 1.564469 & 1.118071 & 1.144454 & 3.453689 & 5.00073 & 1.19246 & 2.56533 \\
\hline GO & 0 & 0 & 2.854729 & 0 & 0 & 45.0908 & 3.64369 \\
\hline HFO & 0 & 0 & 0 & 0 & 2.06124 & 0 & 2.38857 \\
\hline CO & 0 & 0 & 0 & 1.442981 & 0 & 1.96101 & 0 \\
\hline
\end{tabular}

Table 8: Water Consumption within Station (IG/MBTU)

\begin{tabular}{|c|c|c|c|c|c|c|c|}
\hline Fuel & Shuwaikh & $\begin{array}{l}\text { Shuaiba } \\
\text { South }\end{array}$ & Shuaiba North & Doha East & $\begin{array}{l}\text { Doha } \\
\text { West }\end{array}$ & $\begin{array}{l}\text { Az-Zour } \\
\text { South }\end{array}$ & Sabiya \\
\hline NG & 4.578251 & 6.416466 & 8.32689 & 26.21870 & 17.62 & 6.65634 & 11.5982 \\
\hline GO & 0 & 0 & 20.77060 & 0 & 0 & 251.697 & 16.4736 \\
\hline HFO & 0 & 0 & 0 & 0 & 7.26275 & 0 & 10.799 \\
\hline CO & 0 & 0 & 0 & 10.95440 & 0 & 10.9464 & 0 \\
\hline
\end{tabular}


Table 9: Water Production (IG/MBTU)

\begin{tabular}{|cccccccc|} 
Fuel & Shuwaik & $\begin{array}{c}\text { Shuaiba } \\
\text { South }\end{array}$ & $\begin{array}{c}\text { Shuaiba } \\
\text { North }\end{array}$ & Doha East & Doha West & $\begin{array}{c}\text { Az-Zour } \\
\text { South }\end{array}$ & Sabiya \\
\hline NG & 628.1042 & 195.4285 & 219.1194 & 556.6303 & 921.279 & 161.69 & 373.645 \\
\hline GO & 0 & 0 & 546.5717 & 0 & 0 & 6113.99 & 530.709 \\
\hline HFO & 0 & 0 & 0 & 0 & 379.74 & 0 & 347.899 \\
\hline CO & 0 & 0 & 0 & 232.5649 & 0 & 265.899 & 0 \\
\hline
\end{tabular}

Table 10: Water Consumption and Total Electricity Production for each Station

\begin{tabular}{|ccc|}
\hline Station & $\begin{array}{c}\text { Water Consumption within Station } \\
\text { (IG/MBTU) }\end{array}$ & $\begin{array}{c}\text { Total Electricity Production (MWh) } \\
\text { Shuaiba South }\end{array}$ \\
\hline Shuaiba North & 29.416465637 & 393,260 \\
\hline Doha East & 30.905167 & 455,077 \\
\hline Doha West & 24.883 & 517,800 \\
\hline Az-Zour & 269.3 & $1,136,080$ \\
\hline Sabiya & 38.8707 & $2,974,074$ \\
\hline
\end{tabular}

Table 10 indicates that the highest amount of electricity was produced at Az-Zour station with total around $3 \mathrm{MWh}$ followed by Sabiya and Doha west, as a result, water consumption was at the same order. Although there was around 672,737 MWh difference in electricity production between Az-Zour and Sabiya, water consumption at Az-Zour was much higher than that at Sabiya. But referring to water consumption values for each fuel in Table 8, it indicates that there was a high water consumption at Az-Zour station when using gas oil and it was the highest value within stations, it was also much higher than water consumed value for gas oil in Sabiya and Shuaiba North station although these stations are older than Az-zour but the difference comes from cooling system at Az-Zour which was disabled in that time so huge amounts of water was required for of cooling.(Ministry of Electricity and Water)

Gas oil consumed water more than other fuels in Shuaiba North, Az-Zour South and Sabiya stations, and natural gas consumed water more than crude oil and HFO in Doha East and Doha West, respectively.

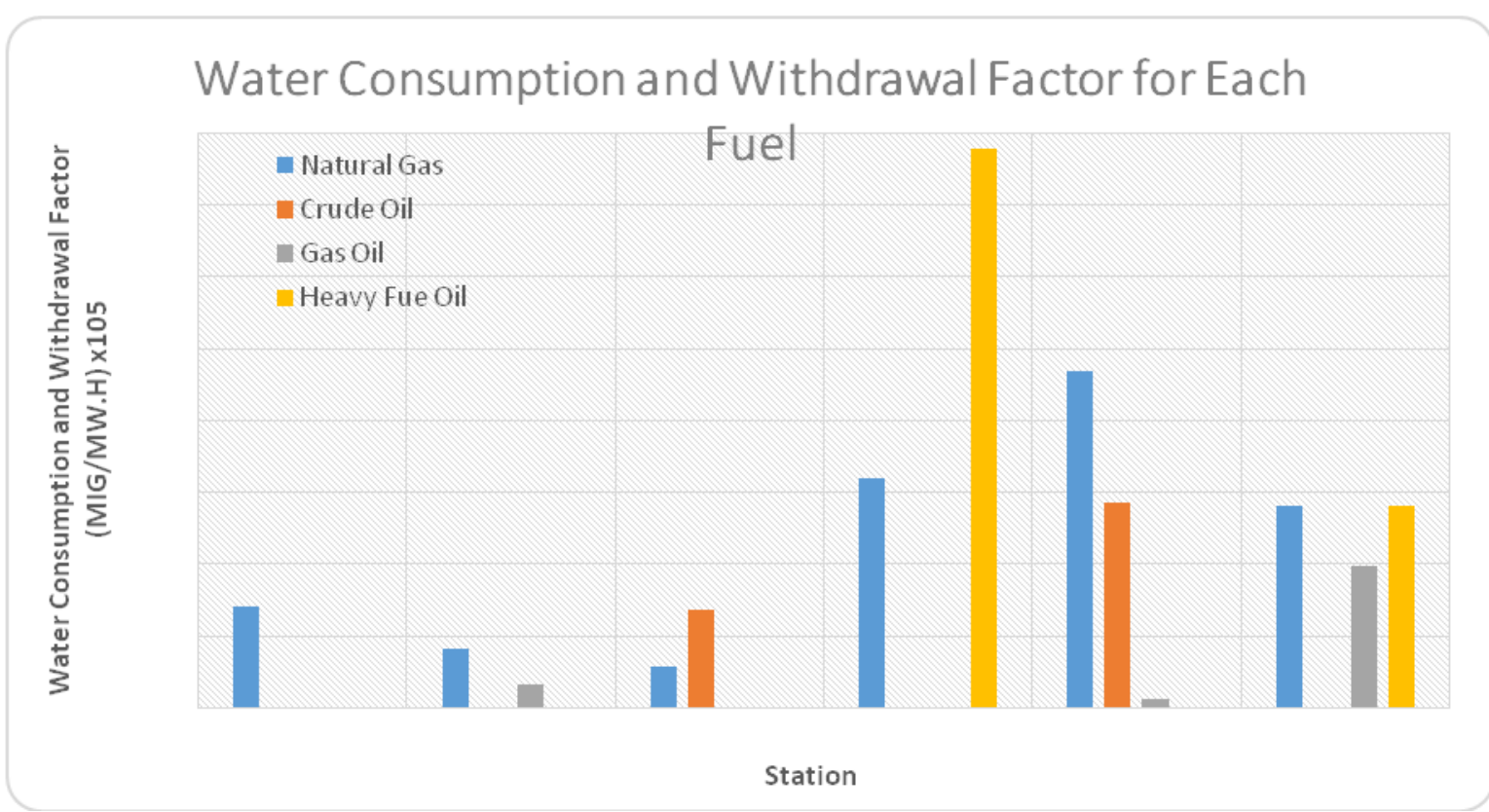

Figure 1: Water Consumption and Withdrawal Factor in each Station for each Fuel

From Table 7 - 9, figure 1 was obtained and from this figure, it is noticed that for natural gas, water consumption and withdrawal factor is the minimum which means that the water consumed when the station is using natural gas is less as was proved. The opposite was seen in both Shuaiba 
North and Doha West stations; this may be because of the high natural gas percentage used in those stations with $70 \%$ and $60 \%$ respectively. Refer to excel data sheet. Water consumption factor for Shuwaikh had not been determined since electricity production in this station is Zero. Thus, this station produces water only.

\section{Optimal Fuel for Water Reduction}

Optimal fuel must consume minimum water and cost minimum charges for electricity production. Cost of each fuel in KD/BTU had been calculated using table 4 and cost of each fuel used in each station calculated per each MWh produced and it is shown in Tables 11 and 12, respectively.

Table 11: Cost of Fuel in KD/BTU

\begin{tabular}{|cc|}
\hline Fuel Type & KD/BTU \\
\hline NG & 5.652 \\
\hline HFO & 4.595 \\
\hline CO & 5.427 \\
\hline GO & 6.247 \\
\hline
\end{tabular}

Table 12: Cost of Electricity produced KD/MWh

\begin{tabular}{|ccccc|}
\hline $\begin{array}{c}\text { Station/Fuel Type } \\
\text { Shwaikh }\end{array}$ & \multicolumn{1}{c}{$\begin{array}{c}\text { Natural Gas } \\
\text { Shuwaikh Station Produces Water only without Electricity. }\end{array}$} \\
\hline Shuaiba South & 61.90728 & 0 & 0 & 0 \\
\hline Shuaiba North & 55.2078 & 0 & 60.77196 & 0 \\
\hline Doha East & 70.90564 & 68.0908 & 0 & 0 \\
\hline Doha West & 60.37893 & 0 & 0 & 49.094736 \\
\hline AZ-Zour South & 53.12688 & 51.017863 & 58.72183 & 0 \\
\hline Sabiya & 53.04167 & 0 & 58.6276 & 43.12874 \\
\hline
\end{tabular}

Gas oil is more expensive than other fuels as it is seen in table 11, where crude oil and heavy fuel oil are cheaper than natural gas.

Scenarios Water Consumption and Cost Difference

\section{Scenario \#1: Doha East}

Assuming equal quantity from both natural gas and crude oil (increase percentage of natural gas) caused water consumption to decrease, but 300,000 $\mathrm{KD}$ increase in gross fuel price occurred, it is refer to the cost of natural gas which is higher than crude oil as it was discussed earlier. The following table shows the difference between the base case and scenario \#1 for both water consumption and gross fuel cost.

Table 13: Water Consumption and Gross Fuel Price for Scenario \#1

\begin{tabular}{|ccc|}
\hline Case & $\begin{array}{c}\text { Water Consumption } \\
\text { within Station (IG/MBTU) }\end{array}$ & $\begin{array}{c}\text { Gross Fuel Price } \\
\text { (KD) }\end{array}$ \\
\hline Doha East: $(\mathbf{3 0 \%}$ NG, 70\% CO) & 37.173104 & $35,686,942.59$ \\
\hline Scenario \#1: $(\mathbf{5 0 \%}$ CO, 50\% NG) & 30.905167 & $35,986,179.29$ \\
\hline
\end{tabular}

\section{Scenario \#2: DohaWest}

Since more than two third of the used fuel in Doha West station is heavy fuel oil, it had been assumed that heavy fuel oil cover only $40 \%$ of the station demands and natural gas would be used with the percentage of $60 \%$, then water consumption would decrease by $3 \mathrm{IG} / \mathrm{MBTU}$ but gross fuel price would significantly increase to about 4 million $\mathrm{KD}$ as shown in the following Table:

Table 14: Water Consumption and Gross Fuel Price for Scenario \#2

\begin{tabular}{|ccc|}
\hline Case & $\begin{array}{c}\text { Water Consumption } \\
\text { within Station (IG/MBTU) }\end{array}$ & $\begin{array}{c}\text { Gross Fuel Price } \\
\text { (KD) }\end{array}$ \\
\hline Doha West: $(\mathbf{3 0 \%}$ NG, 70\% HFO) & 24.883 & $59,517,361.09$ \\
\hline Scenario \#2: $(\mathbf{4 0 \%}$ HFO, 60\% NG) & 21.429 & $63,467,393.11$ \\
\hline
\end{tabular}




\section{Scenario \#3: Az-Zour}

Az-Zour station uses three types of fuels; contrary to what had been imposed in previous scenarios decrease in natural gas percentage had been assumed to the half of it original value with increase in crude oil and remaining the gas oil as it was. As expected, water consumption increased but not dramatically, on the other hand, around 2 million KD would be saved, the following table summarizes results:

Table 15: Water Consumption and Gross Fuel Price for Scenario \#3

\begin{tabular}{|lcc|}
\multicolumn{1}{|c}{ Case } & $\begin{array}{c}\text { Water Consumption } \\
\text { within Station (IG/MBTU) }\end{array}$ & $\begin{array}{c}\text { Gross Fuel } \\
\text { Price (KD) }\end{array}$ \\
\hline Az-Zour (37.2\% CO, 1.6\% GO, 61.2\% & 268.26894 & $155,939,021.5$ \\
\hline $\begin{array}{c}\text { Scenario \#3: (68.4\% CO, 1.6\% GO, } \\
\text { 30\% NG) }\end{array}$ & 270.19497 & $153,983,221.6$ \\
\hline
\end{tabular}

According to the previous discussion the third scenario is the best one that had been considered

\section{Scenario \#4: Shuaiba}

Assuming that Shuaiba North uses only natural gas rather than natural gas and gas oil, thus as shown in the following table, water consumption would be decreased five times in addition to 700,000 KD saving would be attained but electricity production decreased five times, which means that gas oil is the most expensive and most water consuming fuel but it's productivity of is less than other fuels.

Table 16: Water Consumption, Electricity Production and Gross Fuel Price for Proof Scenario

\begin{tabular}{|cccc|}
\hline Station & $\begin{array}{c}\text { Electricity } \\
\text { Produced } \\
\text { (MW.h/TBTIU) }\end{array}$ & $\begin{array}{c}\text { Water } \\
\text { Consumption within } \\
\text { Station (IG/MBTU) }\end{array}$ & $\begin{array}{c}\text { Gross Fuel Price } \\
\text { (KD) }\end{array}$ \\
\hline $\begin{array}{c}\text { Shuaiba North } \\
(\mathbf{3 0 \%} \text { GO, 70\% NG) }\end{array}$ & 501.1390 & 29.0974 & $25,848,420.82$ \\
\hline $\begin{array}{c}\text { Shuaiba North } \\
(\mathbf{1 0 0 \%} \text { NG) }\end{array}$ & 102.3715 & 5.94396 & $25,123,798.36$ \\
\hline
\end{tabular}

\section{SUMMARY}

The seven stations of Kuwait were considered in this study. Electricity and water consumption and production for each fuel had been calculated for each station. Water consumption and/or withdrawal factor then had been calculated depending on these values. For electricity future scenarios, these detailed water consumption and/or withdrawal factors can be utilized in energyeconomic models to better understand the regional and national impacts on water resources. Costs of each fuel was calculated and then cost of each MWh produced using each fuel was calculated. Four scenarios on Doha East and West, Az-Zour and Shuaiba North stations had been considered. The best scenario was Az-Zour scenario where the other scenarios gave expected results. Natural gas is the best fuel for reducing water consumption but to produce huge amount of electricity huge amounts of natural gas are required. Crude oil is cheaper than N.G and consumes moderate amounts of water and it produces more electricity than natural gas does. Gas oil is the worst fuel among all other fuels; it consumes huge amounts of water and costs more than all of them to produce similar amounts of electricity. On the other hand, heavy fuel oil is the cheapest and same as crude oil, produces good amounts of electricity and consumes moderate amounts of water.

\section{CONCLUSION}

This study is concerned in determining the optimum fuel for reducing water consumption and cost without affecting the production of electricity in Kuwait power plants. Electricity demand is continuously increasing; hence as electricity production increases, water consumption and cost both will increase. Consumption of water within the station depends on different factors including the type of fuel used, age of turbines, age of the station, maintenance of equipment, and the location of the plant, the study concerns type of fuel used only. After conducting different scenarios, it was observed that although natural gas is the least water consuming but it is more expensive than crude oil and heavy fuel oil and its electricity production is lower than all other types of fuels. Where Crude oil consumes water more than natural gas does but it costs less and produces more electricity if the same heat content in BTU will be used. Gas oil is the fuel that should be avoided, because it consumes huge amount of water among all fuels and it is the most 
expensive one. Thus, eliminating this type of fuel will reduce both cost and water consumption. As it had been proved in the fourth scenario. Heavy fuel oil on the other hand, consumes moderate amounts of water and it is the cheapest fuel among other fuels. So it gives lower cost and better productivity in electricity generation. It is not reasonable to conclude or determine the optimum fuel because of limited analysis and time. Future work should consider more scenarios especially for Az-Zour station in addition to study more factors such as the age and type of turbine since they can affect the amount of water consumed and electricity produced in the station. Thus, using of an Optimization model to determine an exact estimation of optimum fuel or combination of different fuels is required for more accurate results.

\section{REFERENCES}

[1]. AlHajeri, N. S., P. Donohoo, A. S. Stillwell, C. W. King, M. D. Webster, M. E. Webber and D. t. Allen (2011). "Using Market-Based Dispatching With Environmental Price Signals to Reduce Emissions and Water Use at Power Plants in the Texas Grid." Environmental Research Letters: 9.

[2]. Camden (2012). Combined Heat and Power: Air Quality Guidance for Local Authorities. E. P. UK.

[3]. Clark, C., H. Harto, J. Sullivan and M. Wang (2011). Water Use in the Development and Operation of Geothermal Power Plants. ANL/EVS/R-10/5. Argonne, IL: Argonne National Laboratory.

[4]. Dziegielewski, B. and T. Bik (2006). "Water Use Benchmarks for Thermoelectric Power Generation." Research Report of the Department of Geography and Environmental Resources.

[5]. Feeley, T. J., T. J. Skone, G. J. Stiegel, A. McNemar, M. Nemeth, B. Schimmoler, J. T. Murphy and L. Manfredo (2007). "Water: A Critical Resource in the Thermoelectric Power Industry." Energy 33(1): 11.

[6]. Kenny, J. F., N. L. Barber, S. S. Huston, K. S. Linsey, J. K. Lovelace and M. A. Maupin (2005). "Estimated Use of Water in the United States in 2005." U.S. Geological Survey Circular 1344. Reston VA, USGS: 2009: p. 52.

[7]. Kuwait.Fuel-Logistics.Capacity.Assessment. Retrieved 7th.December.2016, from dlca.logcluster.org

[8]. Kuwait.Year.Book. (2010). "Electrical Energy, Ministry of Water and Electricity."

[9]. Macknick, J., R. Newmark, G. Heath and K. C. Hallett (2012). Operational Water Consumption and Withdrawal Factors for
Electricity Generating Technologies: A Review of Existing Literature. National Renewable Energy Laboratory, Golden, CO 80401-3305, USA

[10]. Macknick, J., R. Newmark, G. Heath and K. C. Hallett (2012). "Operational Water Consumption and Withdrawal Factors for Electricity Generating Technologies: A Review of Existing Literature." Environmental Research Letters 7(4).

[11]. Mielke, E., L. D. Andon and V. Narayanamurti (2010). Water Consumption of Energy Resource Extraction, Processing, and Conversion. Harverd Kennedy School, Belfer Center for Science and International Affairs: 1-49.

[12]. Miller, B. A., V. Alavian, M. D. Bender, D. J. Benton, J. P. Ostrowski, J. A. Parsly and M. C. Shiao (1992). "Integrated Assessment of Temperature Change Impacts on the TVA Reservoir and Power Supply Systems." Hydraulic Engineering: Saving a Threatened Resource-In Search of Solutions: Proceedings of the Hydraulic Engineering Sessions at Water Forum '92: p. 563 - 568.

[13]. Ministry.of.Water

[14]. http://www.mew.gov.kw. Accessed 22 November 2016.

[15]. Pokale, W. K. (2012). "Effect of Thermal Power Plant on Environment "Scientific Reviews and Chemical Communications 2(3): 212 - 215.

[16]. Ryan, V. (2009). "The Storage/Disposal of Radioactive Waste Produced by Nuclear Power Stations." The World Association of Technology Teachers.

[17]. World.Energy.Resources. "World Energy Resources." Retrieved 7th.December.2016, from

https://en.wikipedia.org/wiki/World_energy resources.

[18]. Wu, M., M. Mintz, M. Wang and S. Arora (2009). Consumptive Water Use in the Production of Ethanol and Petroleum Gasoline., Argonne National Laboratory, Oak Ridge, Tennessee.

[19]. Yang, X. and B. Dziegielewske (2007). "Water Use by Thermoelectric Power Plants in the United States." J. Am. Water Resour. Assoc 43: pp. 160-169.

[20]. Zabel, G. (2009). Peak People: The Interrelationship Between Population Growth and Energy Resources Energy Bulletin 